\title{
CANADIAN JOURNAL OF
}

\section{Disability Studies}

Canadian Journal of Disability Studies

Published by the Canadian Disability Studies Association Association Canadienne des Études sur le Handicap

Hosted by The University of Waterloo

$\underline{\text { www.cjds.uwaterloo.ca }}$

cjdseditor@uwaterloo.ca

This document has been made accessible and PDF/UA compliant by Accessibil-IT Inc.

For more information go to

http://www.accessibilit.com 


\title{
Judith Butler, Zeynep Gambetti, and Leticia Sabsay (2016). Vulnerability in Resistance. Durham and London: Duke University Press ISBN: 978-0-822-362906
}

\author{
Reviewed by Chelsea Temple Jones \\ Ryerson University \\ chelsea.jones@ryerson.ca
}

In Vulnerability in Resistance, editors Judith Butler, Zeynep Gambetti, and Leticia Sabsay explain that the work of taking up both vulnerability and resistance as a generative pairing of concepts comes with claims "both risky and true". They point to the construction of "the suffering other" as an emergent part of social relations, explaining vulnerability as a process both exacerbated and disavowed as means of achieving power (4). The editors caution that any socially disadvantaged group, such as disabled people, are vulnerable when they must turn to paternalistic institutions for protection. The key question, then, is how to address vulnerability in resistance politically, through corporeal strategies that target such institutions in times of neoliberal austerity (3). As a means of response, this collection asks readers to dwell in vulnerability as more than simply the opposite of resistance - a useful orientation for readers who may already take up both concepts critically, but perhaps not often together.

Judith Butler opens this collection with a chapter titled "Rethinking Vulnerability and Resistance." Here, Butler writes about precarity. She sets up a shifting, interactive, and uneven political terrain that moves past the assumed sequence; namely, that we are first vulnerable and then we overcome vulnerability by resisting the oppressive conditions that characterize our lives (12). Butler is writing about space and infrastructure; access points that should concern us all: paved streets, working toilets, housing, a lack of it, and so on. She points out that our assemblies depend on the infrastructural goods for which we are fighting (13): 
We cannot talk about the body without knowing what supports that body and what its relation to that support—or lack of support—might be. In this way, the body is less an entity than a relation, and it cannot be fully dissociated from the infrastructural and environmental conditions of its living (19).

Butler re-threads her earlier formulations of gender as performative to make her key argument: when the body is both performative and relational we cannot understand bodily vulnerability outside of social and material conditions - a premise long familiar in disability studies (16). The chapter also spins "linguistic vulnerability" in a few directions - wherein performativity demonstrates that we are vulnerable to discourses we may never choose: public media, dependencies, political imprisonment, and imprisonment by other means (such as the administration of violence through prison industries - another argument that rests on the brink of disability studies discussions about re/incarceration) (24).

"Resilience has friends in high places," responds Sarah Bracke, as if in collegial retort to Butler's writing on vulnerability (52). In the third chapter, "Bouncing Back: Vulnerability and Resistance in Times of Resilience”, Bracke interrogates the embodied concept of resilience as a cultural keyword that stands not only for resisting the oncoming and ongoing damage of neoliberalism, but also for "bouncing back" and surviving. The resilient subject—herself gendered, to be sure - finds a place in a neoliberal era where "resilience is the new security" against the normalized threats of environmental, social, and political disaster (57). In this context, where "the contemporary conditions of precarity are (designed to be) met with resilience..." (60), the resilient subject struggles to be constantly productive. Disability studies is, again, well acquainted with the demands for productivity under neoliberalism and 
contemporary operations of power that position subjects as successful depending on the ability to engage in processes of overcoming. However, Bracke cautions readers about the ways resilience undermines our imaginings of possible futures and offers a discursive exploration of futurity wherein the body resists resilience at great cost and great possibility.

What follows in the volume is a decided launch toward corporealities - and some complex connections to disability studies_-beginning with one woman's account of her own cultural and linguistic displacement. In the fourth chapter, "Vulnerable Times," Marianne Hirsch calls up her 13-year-old, U.S.-landed Jewish and German-speaking self, who is coming to terms with postwar communist Romania. She writes up vulnerability through aesthetic encounters: “our acts of reading, looking and listening" (82). These acts, she argues, are productive (rather than resilient) in vulnerable times because they motivate memory and orient us toward a politics of accountability as a form of attunement. Calling for "solidarity that is suspicious of an easy empathy," (84) Hirsch opens the book for a wide audience, addressing whichever social groups can claim memories of vulnerability and resistance — whomever has felt "a frustration with the unforgiving temporality of trauma and catastrophe, the sense of inexorable repetition of the past in the present and a future in which injury cannot be healed or repaired, but lives on, shattering worlds in its wake" (81).

Vulnerability in Resistance also evokes both natality and mortality as themes behind human action; themes to re-script womanhood and critique citizenship. For instance, in the second chapter, “Rethinking Oneself and One’s Identity: Agonism Revisited," Zeynep Gambetti uses Hannah Ardent's connections between acting and suffering as a way to reflect on the 2013 Occupy Gezi movement. She offers snapshots of protests where soccer fans and queer activists find themselves in the same place, at the same time, pushing in the same direction against 
inevitable persecution. Gambetti asks if vulnerability can "encompass permeability and receptiveness" (29) in moments like these - moments that are "non-negotiable through political norms" (39). She is deconstructing binaries between vulnerability and power, materiality, and discursivity, "between too much and too little" (29) as her writing paints a picture of the violence of antagonism. Gambettti's work nods to the book's fifth chapter, "Barricades: Resources and Residues of Resistance," wherein Başka Ertür holds up the figure of the barricade as both metaphor and monument. Agonism emerges again in Chapter twelve through Athena Athanasiou's writing about Women in Black (WiB), a group at the siege of Sarajevo publicly mourning dead bodies (meaning physical bodies, possibilities, communities, and so on) of the "other side" as modes of non-sovereign agency $(257,269)$. This action of mourning others beside ourselves ("beyond and against the proper meaning and 'common places' of home and homeland") is a gesture of performativity and disloyalty — to state, gender, and fixed identity politics (259).

The collection's occupation of the body goes further: In the tenth chapter "Violence against Women in Turkey: Vulnerability, Sexuality, and Eros," Meltem Ahiska asks how systemic, patriarchal violence sustains and reproduces itself while feminist and state-run antiviolence campaigns gain momentum (224). Her answer, in part, points to representations of women's mutilated bodies in such campaigns (220). Such representations reaffirm vulnerability as an apparently natural part of womanhood, while also individualizing and anonymizing women's experiences. Such representations "[create] an alarm not to activate women against violence but to threaten them with violence," she explains (222). Meanwhile, Elsa Dorlin asks questions about civic participation, and how it is possible to intelligibly appear in public space in the eleventh chapter, "Bare Subjectivity: Faces, Veils, and Masks in the Contemporary 
Allegories of Western Citizenship." Dorlin queries the differences between "the shown and the hidden" in contexts where the face signals our inner self and navigates social interactions (236) — where emotion and civility rub up against each other in creating subjectivity and demarking citizenship. Further, in the seventh chapter "Vulnerable Corporealities and Precarious Belongings in Mona Hatoum's Art," Elena Tzelepis asks what kinds of bodies are de/formed through loss, displacement, and occupation using art to demonstrate the abject, familiar, and estranged (147). Similarly, Rema Hammami’s chapter, "Precarious Politics: The Activism of 'Bodies that Count' (Aligning with Those That Don't) in Palestine's Colonial Frontier' describes gendered bodies coming together as they are under erasure in colonial space.

The book winds down with a surprising turn where Nukhet Sirman describes transgressive discourse emerging between feminists from the Kurdish movement and secondwave-style feminism in Istanbul. In the ninth chapter of this collection Sirman chronicles gendered political practices (transgressions) surfacing where Turkish security forces have not allowed families to bury their "ungrievable" (read: terrorist) dead (195). This chapter, "When Antigone Is a Man: Feminist 'Trouble' in the Late Colony," stands out from the others, with the author explaining upfront that writing about vulnerability and transgression in tandem for an academic audience is difficult, especially when the subject is positioned outside the terms of accepted politics. The subject, she writes, "thus becomes vulnerable to blows from all sides, including the academy” (191). Specifically, Sirman describes the case of a man, Hüsnü Yildiz, popularly nicknamed Antigone for his public appeal to have his brother, a guerrilla fighter, buried in a "proper tomb" rather than in a state-sanctioned mass grave (196). This "gender switch" feminizes Yildiz and therefore casts him as vulnerable, insofar as it confuses both gender and kinship norms in a gesture of collective resistance integral to Yildiz's individual protests. 
Yet, such feminization also turns attention toward women as revolutionary figures amid patriarchal rulings (198-199). "Being vulnerable and becoming vulnerable are merged in a political practice that places the troubling term 'woman' at the center of its discourse and practice," Sirman reminds readers (199). "When Antigone is a man and the leader of a guerrilla force is a feminist who talks about the culture of rape and proposes a science of woman as a way of revolutionizing society, the effect is one of transgression," she explains (204). And by this, she means a transgression that falls outside of feminist canons. That academic critique can get in the way of transgression is an argument that, at times, seems both relevant and out of place in this text and in the field of disability studies.

Finally, wedged in the center of this collection is a gripping piece of writing - a reprieve that tasks us with yet another way of knowing: dreaming. In the sixth chapter, "Dreams and the Political Subject," Elena Loizidou presents dreams as politically viable; as one form of motivation toward our politics (139). She argues that dreaming is part of our political existence, despite a theoretical landscape that might suggest otherwise. It is through dreams that we access a sensual world (of writing) integral to politics, and thus integral to political subjectivity (126). Through dreaming, Loizidou asserts, we "recompose ourselves" (124). She adds an esoteric twist to Butler's earlier questions of access by bringing up questions of access to knowledge.

Guiding this 352-page meditation on the intertwining of vulnerability and resistance is the notion that vulnerability is a resource that we can be exposed to willingly, or that we might claim, and from here resistance emerges in our bodies in and through radical democratic practices (279). Broadly speaking, the writers in this collection make a case for linking corporeality and subjectivity in a re-emergence of the topics: vulnerability in resistance. As 
Leticia Sabsay remarks in the book's conclusion, vulnerability in resistance denotes an affective dimension of politics that should be of concern and contestation to all bodies in neoliberal times.

"However," Sabsay explains, "it might be the case that this critical insight into vulnerability only goes part of the way" (279). Yet, the overall text also reminds us that complete thoughtsvisions of finality—do not constitute the subject. Rather, we are working through the living and the dead, the memories and the present, the barricades and the dreams as we aim to include vulnerability/resistance — and their political characters—in our thoughts (280). The editors charge us to think through "part of the very meaning of political resistance as an embodied enactment" and the problems that come with its different forms (22). Important for disability studies is the authors' collective critique: when vulnerability becomes a group identification - as it does in global and local descriptions of disability — this marking strengthens paternalistic power (24-25). The call to action here? Dismantle the binary relationship between vulnerability and resistance. 